\title{
Box-Girder Bridges - Modelling and Analysis
}

\author{
Preeti Agarwal, Priyaranjan Pal, Pradeep Kumar Mehta \\ Civil Engineering Department, MNNIT Allahabad, Prayagraj, INDIA \\ e-mails: gotopreetiagarwal@gmail.com; prpal2k@gmail.com; pradeep11@mnnit.ac.in
}

\section{SUMMARY}

The box-girder bridge has become very popular lately due to its serviceability, stability, and structural efficiency. The study of such a bridge requires analytical, experimental, or numerical methods. The structural behavior of the box-girder bridge is very complex and is quite cumbersome to be investigated by conventional methods. This paper presents a modelling process for the analysis of simply supported reinforced concrete (RC) box-girder bridges (straight, skew, curve, and skew-curved) using the finite element method under Indian loading conditions. This modelling process is developed on the basis of the Codal provisions of Indian Road Congress (IRC) 6:2017 and IRC 21:2000, and its implementation is quite simple as it avoids the cumbersome calculations and requires less time. Different values of the span, span-depth ratio, and the number of cells are considered to suit the requirements, and limiting criteria for stresses and deflection are checked. The static and free vibration analyses are carried out, and the results are compared to control the applicability of the proposed modelling process. The present modelling process is applied to analyse the RC box-girder bridges up to $50 \mathrm{~m}$ spans, and no erection procedure is included. However, one may follow the proposed modelling procedure for any box-girder bridge for its analysis.

KEY WORDS: box-girder bridge; static analysis; dynamic analysis; Indian Road Congress; reinforced concrete.

\section{INTRODUCTION}

A bridge is a structure designed to transport road traffic or other moving loads over a barrier or other infrastructure. Box-girder bridges are becoming popular nowadays and have firmly established themselves in medium and long-span bridge constructions. The small-span bridge is uncommon in concrete box-girder bridges. However, in Table 1 are some examples of reinforced concrete box-girder bridges erected in India with spans ranging from 25 to $50 \mathrm{~m}$. The use of a simply supported small-span bridge may be due to soil characteristics and heavier reinforced concrete sections. A broad deck with long-span and eccentric loading experiences severe deflection in both the longitudinal and lateral directions that causes serious crosssection distortion. These bridge decks also require high torsional rigidity to mitigate the impact of deck distortion. Thus, for a longer span, broader deck and larger depth, a box-girder 
bridge has been proven to be an appropriate choice. Other problems like alignment constraints, land acquisition, etc. are also taken care of effectively with the introduction of skewness and/or curvature in box-girder bridges. With the introduction of skewness and curvature, the analysis becomes very complicated, and the Indian codes are silent about the analysis and design of such bridges. The box-girder bridges can be studied using experimental, analytical and numerical methods. Here, the experimental method is the costlier one, whereas the analytical is very complicated. Due to the simplicity of execution and applicability on complicated bridges, numerical techniques have gained popularity in the last few decades. A substantial literature on the analysis and design of box-girder bridges is presented below.

\begin{tabular}{|c|l|c|l|}
\hline \multicolumn{4}{|c|}{ Table 1 Reinforced concrete box-girder bridges in India } \\
\hline S. No. & \multicolumn{1}{|c|}{ Bridge } & Span & \multicolumn{1}{|c|}{ Location } \\
\hline 1 & $\begin{array}{l}\text { Railway box type minor bridge of 13.5 m span along the } \\
\text { route via. Mughalsarai to New Karchana station }\end{array}$ & $13.5 \mathrm{~m}$ & Uttar Pradesh \\
\hline 2 & Box-girder bridge over Man Khad, Barsar & $30 \mathrm{~m}$ & Himachal Pradesh \\
\hline 3 & Mumbai Ambedkar road flyovers & $35 \mathrm{~m}$ & Maharashtra \\
\hline 4 & Box-girder bridge, DMRC & $40 \mathrm{~m}$ & New Delhi \\
\hline
\end{tabular}

Brown and Ghali [1] presented a semi-analytic method for the skew box-girder bridges' analysis and compared those results with the experimental ones. The bridge is assumed to be made by parallelogrammic strips. Heins and Oleinik [2] analysed the single and multi-span curved single box-girder bridges using the finite element difference method. Panayotounakos and Theocaris [3] performed the static analysis and presented the close form solution of a continuous skew-curved beam based on the superposition principle. Six degrees of freedom (three translations and three rotations) at each node were used in the analysis. Cheung et al. [4] used orthotropic plate theory for the analysis of curved bridges and validated their results with the grillage method. Evans [5] used a folded plate method for the analysis of the curved box-girder bridge. Zhang and Lyons [6] analysed a curve box-girder bridge using the thinwalled beam theory and the finite element method. Three extra degrees of freedom were assumed to take into account the warping and distortional effects. Shushekewich [7] used membrane equations to analyse three-dimensional box-girder bridges and compared their results with folded plate method. Li et al. [8] proposed a method for analysing circular and non-circular box-girder bridges using the spline finite strip method. Webs and flanges are modelled by using thin shells and flat curved plates, respectively, to consider the effect of curvature. Arizumi et al. [9] investigated the composite box-girder bridges experimentally and compared the results with the analytical methods (Finite strip method, curved beam theory and distortional theory). Bakht [10] analysed the skew box-girder bridge analytically, considering American Association of State Highway and Transportation Officials (AASTHO) specifications. Ebeido and Kennedy [11, 12] performed the finite element analysis on the simply supported composite steel-concrete bridges subjected to Ontario Highway Bridge Design Code (OHBDC) truck loading. Luo and Li [13] investigated the effect of shear lag in thinwalled curved box-girder bridges. The equilibrium equation was developed with a thin-walled curve bar theory and the potential variational principle. Huo et al. [14] investigated the shear distribution factor of Buffet Mill road RC box-girder bridge of span length $42.67 \mathrm{~m}$ located in the United States. Song et al. [15] investigated the moment and shear of box-girder bridges 
under HL93 truck load as per the limits imposed by the AASTHO-LRFD specifications. Jawanjal and Kumar [16] studied a simply supported box-girder RC bridge curved in plan with skewed supports, using the finite element method. Nine noded shell elements are used to model the bridge using STAAD.Pro. Ashebo et al. [17] carried out the field test on Yi South skew RC boxgirder bridge of span $27 \mathrm{~m}$ in the New Territories West in Hong Kong. Ates [18] analysed a continuous concrete box-girder bridge (Budan Bridge) using the balanced cantilever method considering the time-dependent material properties of steel and concrete. The model is prepared in the SAP2000 program; the finite element model of the bridge consists of solid elements having 3 degrees of freedom at each nodal point. Su et al. [19] conducted the experiments on two specimens of steel-concrete composite box-girder with the inclined web. Fangping and Jianting [20] investigated the influence of curvature on the deformation of curved bridges using the ANSYS software. The concrete box-girder is modelled with solid elements and the pre-stressed steel tendon with link elements. Mohseni and Rashid [21] analysed the skew multi-cell box-girder bridges (Tennesee bridges) using a finite elementbased software SAP2000. A four noded three-dimensional shell element with six degrees of freedom at each node is used to model the prototype multi-cell box-girder bridges. Choi and Oh [22] proposed the rational method to analyse the deck slab of concrete box-girder bridges. An experimental setup is also developed to validate the results obtained from the numerical model. Arici and Granata $[23,24]$ proposed an analysis method to evaluate the non-uniform torsional effect in a curved concrete bridge using the incremental Hamiltonian launching method. Deng et al. [25] carried out a test on six skew-curved bridges at the northeast corner of Des Moines, Iowa and compared the results with the finite element model. The decks and webs were modelled with the four noded shell elements having six degrees of freedom at each node. Fan et al. [26] analysed a continuous curved box-girder bridge to evaluate the vertical bending, pure torsion, lateral bending, and longitudinal movement, using the finite elementbased software Midas Civil. Kasefi et al. [27] analysed the straight-thin walled steel box-girder bridge using ABAQUS software. Androus et al. [28] carried out experiments on scaled composite concrete double-cell box-girder bridge models. Tiwari and Bhargava [29] presented the load distribution characteristics of straight composite multi-cell box-girder bridges under IRC loads using finite element-based ANSYS software. The shell elements were used to model the bridge. The results were validated with the experimental and numerical (ABAQUS) results. Gupta et al. [30,31] analysed the curved box-girder bridge using SAP2000 software. A four noded shell element with six degrees of freedom was used for discretization. Agarwal et al. [32, 33] analysed the skew box-girder bridge using finite element-based SAP2000 software. The bridge model was discretized by using four noded shell elements. Gupta and Kumar [34] analysed the Han-Jiang bridge of span length $27.4 \mathrm{~m}$, located at Shayang located in Wuhan, China. The skew-curved concrete box-girder bridge was analysed under Indian specification using CSiBridge software [35]. The model was discretized into four noded shell elements with six degrees of freedom at each node.

It is found that numerous kinds of literature are available on the analysis of skew and curved bridges with AASTHO standard loadings. But, only a few pieces of literature are available on the skew-curved box-girder bridges. Further, the study of box-girder bridges under IRC (Indian Road Congress) loading conditions is rarely found in the literature. Only a list of AASTHO and OHBDC specifications and empirical design methods are available to analyse the box-girder bridges. Nevertheless, there are no standard procedures or specifications in the Indian code for the analysis of such bridges. Also, the selection procedure of cross-section considered for the analysis of box-girder bridges is not explained. The above observations 
motivated the authors to provide a generalized modelling procedure for analysing the boxgirder bridges. This study explains the preliminary design and assumptions made in the modelling process for different types of box-girder bridges viz. skew, curved and skew-curved bridges. The modelling and analysis of these bridges are carried out using finite element-based CSiBridge software [36]. As examples, some results are presented for the static and free vibration analyses of box-girder bridges to verify the complete process.

\section{PRELIMINARY DESIGN}

For a safer design, this study provides the basic steps and the appropriate data, i.e., the parameters that affect the behavior of the box-girder bridges. The cross-sectional properties are finalized through preliminary design for various spans and span-depth ratios, as shown in Figure 1.

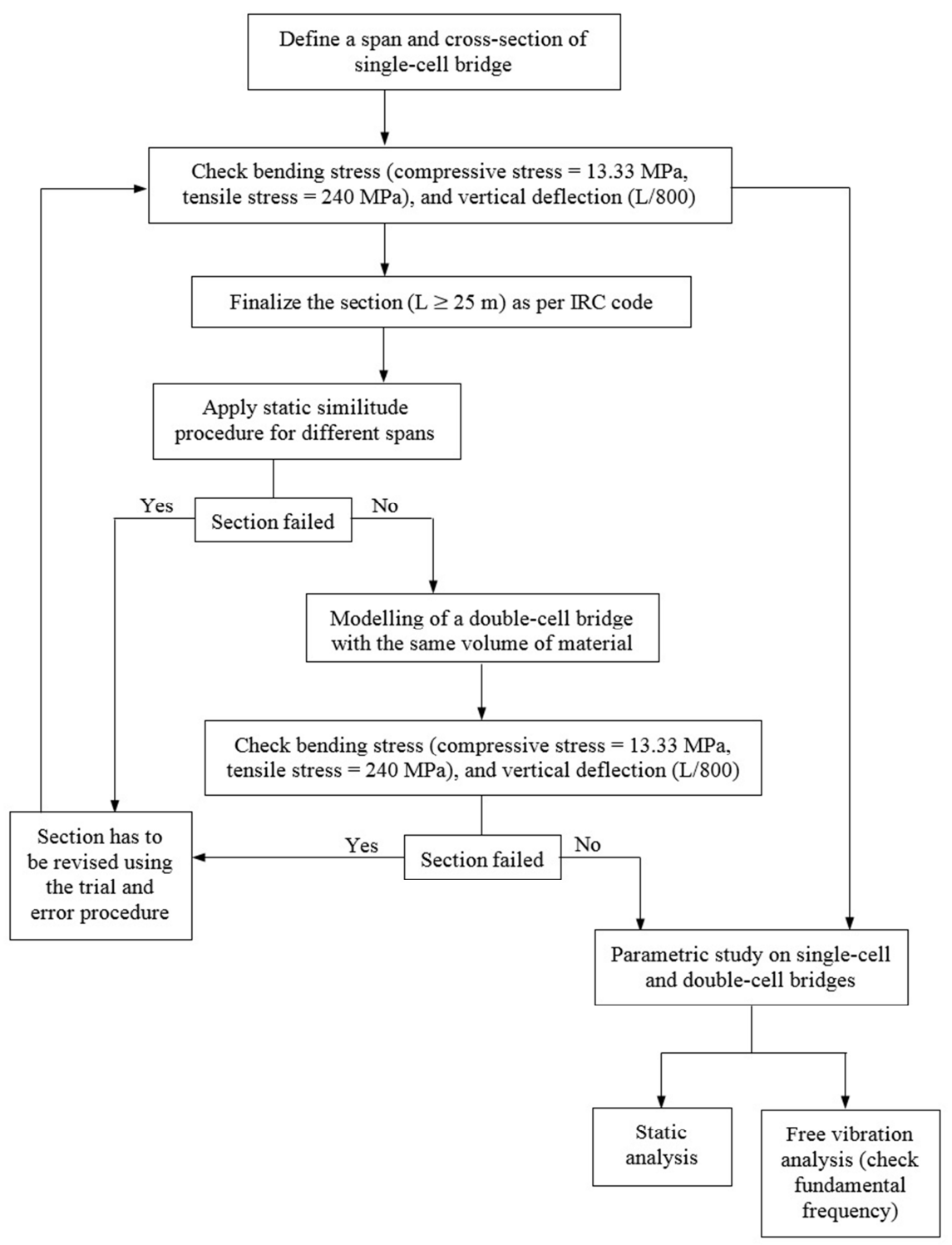

Fig. 1 Flow diagram of analysis for choosing the cross-section 
At first, a particular span $(L)$ and span-depth ratio $(L / d)$ are assumed as $25 \mathrm{~m}$ and 10 , respectively, in the study. The section is finalized according to the specifications made by IRC: 21 [37], IRC: 112 [38], and Rajagopalan [39]. Then, the section is checked for bending stress (compressive stress $=13.33 \mathrm{MPa}$, tensile stress=240 $\mathrm{MPa}$ ) and vertical deflection $(\mathrm{L} / 800$ ), prescribed in IRC: 21 and IRC: 112. If the section passes under the criteria, the section is finalized; otherwise, the section is revised. After that, the static similitude conditions (ratio of all the corresponding linear dimensions in the model and prototype are equal) are applied to estimate other spans' geometrical properties. A span of $25 \mathrm{~m}$ and above is mostly used for boxgirder bridges due to its beneficial structural behavior and intrinsic transverse and torsional rigidities [39]. Several cases for different spans have been examined, and the geometrical properties are predicted using the static similitude principle. The static similitude conditions used are as follows:

1. Scale reduction factor for length:

$K_{L}=L_{p} / L_{m}$

2. Scale reduction factor for area:

$K_{A}=K_{L}^{2}$

3. Scale reduction factor for the moment of inertia:

$K_{I}=K_{L}^{4}$

4. Scale reduction factor for section modulus:

$K_{\mathrm{Z}}=K_{\mathrm{L}}^{3}$

The sectional properties and geometry of the prototype selected are listed in Table 2. The sample calculation for $30 \mathrm{~m}$ span box-girder bridge is as follows:

$$
\begin{aligned}
& K_{L}=L_{p} / L_{m}=25 / 30=0.833 \\
& K_{A}=K_{L}^{2}=(0.833)^{2}=0.694 \\
& K_{I}=K_{L}^{4}=(0.833)^{4}=0.482 \\
& K_{Z}=K_{L}^{3}=(0.833)^{3}=0.579
\end{aligned}
$$

So, the cross-sectional area $(A)=6.42 / 0.694=9.250 \mathrm{~m}^{2}$, the moment of inertia $(I)=6.802 / 0.482$ $=14.112 \mathrm{~m}^{4}$, and the sectional modulus $(Z)=6.735 / 0.579=11.632 \mathrm{~m}^{3}$.

Table 2 Sectional properties of prototype bridge

\begin{tabular}{|c|c|}
\hline Span $(L)$ & $25 \mathrm{~m}$ \\
\hline Cross-sectional area $(A)$ & $6.42 \mathrm{~m}^{2}$ \\
\hline Total Width $(B)$ & $11.5 \mathrm{~m}$ \\
\hline Depth $(D)$ & $2.7 \mathrm{~m}$ \\
\hline Thickness of top flange $\left(t_{t}\right)$ & $0.3 \mathrm{~m}$ \\
\hline Thickness of bottom flange $\left(t_{b} f\right)$ & $0.3 \mathrm{~m}$ \\
\hline Thickness of web $\left(t_{w}\right)$ & $0.3 \mathrm{~m}$ \\
\hline Moment of inertia $(I)$ & $6.802 \mathrm{~m}^{4}$ \\
\hline Sectional modulus $(Z)$ & $6.735 \mathrm{~m}^{3}$ \\
\hline
\end{tabular}


Similarly, the cross-sectional properties of different spans obtained through the static similitude procedure are calculated and are listed in Table 3 for a single-cell box-girder bridge employing similitude conditions.

Table 3 Cross-sectional properties for different spans through similitude

\begin{tabular}{|c|c|c|c|}
\hline$L(m)$ & $A\left(\mathrm{~m}^{2}\right)$ & $I\left(\mathrm{~m}^{4}\right)$ & $Z\left(\mathrm{~m}^{3}\right)$ \\
\hline 25 & 6.420 & 6.802 & 6.735 \\
\hline 30 & 9.250 & 14.112 & 11.632 \\
\hline 35 & 12.583 & 26.130 & 18.481 \\
\hline 40 & 16.435 & 44.577 & 27.586 \\
\hline 45 & 20.800 & 71.404 & 39.278 \\
\hline 50 & 25.680 & 108.832 & 53.880 \\
\hline
\end{tabular}

The above procedure overestimates the cross-sectional properties and makes a box-girder section almost solid (it is not hollow, i.e., the section is filled with materials).

Further, the cross-section of the single-cell bridge, different spans and span-depth ratios are revised using the trial and error method. The bridge is modelled using the cross-sectional properties presented in Table 4, and the results of maximum values of bending stresses and vertical deflection are evaluated for both dead and live (IRC Class 70-R track) loads for different spans and span-depth ratios. Thereafter, the cross-sections of the single-cell bridge are checked for bending stress (compressive stress $=13.33 \mathrm{MPa}$, tensile stress $=240 \mathrm{MPa}$ ) and vertical deflection $(L / 800)$, prescribed in IRC: 21 and IRC: 112 . If the results are within the specified limits of IRC: 21 and IRC: 112, the model is finalized. Otherwise, the whole process is repeated until the results fall within limits. The material of the cross-section is redistributed for the double-cell box-girder bridge and analysed again. The bridge is modelled using the cross-sectional properties presented in Table 5.

Then, the cross-sections of the double-cell bridge are checked once more for bending stress (compressive stress $=13.33 \mathrm{MPa}$, tensile stress $=240 \mathrm{MPa}$ ) and vertical deflection $(L / 800)$. Some sectional properties' values are omitted as they do not meet the strength, serviceability, and inspection conditions specified in IRC. The maximum bending stresses (compressive stress and tensile stress) and vertical deflection of different models for different spans and spandepth ratios, considering concrete characteristic compressive strength as $40 \mathrm{MPa}$ and steel characteristic yield strength as $500 \mathrm{MPa}$, are listed in Tables 6 and 7. Also, these values are compared with the specification prescribed by IRC: 21 and IRC: 112. It is found that the results satisfy the bending stresses and vertical deflection criterion. 
Table 4 Cross-section of single-cell box-girder bridge

\begin{tabular}{|c|c|c|c|c|c|c|c|}
\hline \multirow{2}{*}{$L / d$} & \multirow{2}{*}{ Cross-sectional properties } & \multicolumn{6}{|c|}{$L(m)$} \\
\hline & & 25 & 30 & 35 & 40 & 45 & 50 \\
\hline \multirow{4}{*}{10} & Thickness of top flange, $t_{t f}(\mathrm{~mm})$ & 300 & 300 & 300 & 300 & 300 & 300 \\
\hline & Thickness of bottom flange, $t_{b f}(\mathrm{~mm})$ & 300 & 300 & 320 & 340 & 360 & 380 \\
\hline & Thickness of web, $t_{w}(\mathrm{~mm})$ & 300 & 320 & 340 & 360 & 380 & 400 \\
\hline & Sectional area, $A\left(m^{2}\right)$ & 6.42 & 6.82 & 7.37 & 7.95 & 8.57 & 9.24 \\
\hline \multirow{4}{*}{12} & Thickness of top flange, $t_{t f}(\mathrm{~mm})$ & 300 & 300 & 300 & 300 & 300 & 300 \\
\hline & Thickness of bottom flange, $t_{b f}(\mathrm{~mm})$ & 300 & 300 & 330 & 350 & 400 & 420 \\
\hline & Thickness of web, $t_{w}(\mathrm{~mm})$ & 300 & 325 & 350 & 380 & 400 & 435 \\
\hline & Sectional area, $A\left(\mathrm{~m}^{2}\right)$ & 6.17 & 6.52 & 7.07 & 7.63 & 8.34 & 9.03 \\
\hline \multirow{4}{*}{14} & Thickness of top flange, $t_{t f}(\mathrm{~mm})$ & - & 320 & 360 & 360 & 360 & 380 \\
\hline & Thickness of bottom flange, $t_{b f}(\mathrm{~mm})$ & - & 423 & 450 & 470 & 480 & 490 \\
\hline & Thickness of web, $t_{w}(\mathrm{~mm})$ & - & 500 & 550 & 600 & 650 & 680 \\
\hline & Sectional area, $A\left(\mathrm{~m}^{2}\right)$ & - & 7.69 & 8.77 & 9.48 & 10.2 & 11.08 \\
\hline \multirow{4}{*}{16} & Thickness of top flange, $t_{t f}(\mathrm{~mm})$ & - & - & 320 & 450 & - & - \\
\hline & Thickness of bottom flange, $t_{b f}(\mathrm{~mm})$ & - & - & 480 & 650 & - & - \\
\hline & Thickness of web, $t_{w}(\mathrm{~mm})$ & - & - & 450 & 500 & - & - \\
\hline & Sectional area, $A\left(\mathrm{~m}^{2}\right)$ & - & - & 7.87 & 10.53 & - & - \\
\hline
\end{tabular}

Table 5 Cross-section of double-cell box-girder bridge

\begin{tabular}{|c|c|c|c|c|c|c|c|}
\hline \multirow{2}{*}{$L / d$} & \multirow{2}{*}{ Cross-sectional properties } & \multicolumn{6}{|c|}{$L(m)$} \\
\hline & & 25 & 30 & 35 & 40 & 45 & 50 \\
\hline \multirow{4}{*}{10} & Thickness of top flange, $t_{t f}(\mathrm{~mm})$ & 243 & 243 & 250 & 250 & 255 & 260 \\
\hline & Thickness of bottom flange, $t_{b f}(\mathrm{~mm})$ & 300 & 300 & 300 & 300 & 300 & 300 \\
\hline & Thickness of web, $t_{w}(\mathrm{~mm})$ & 300 & 300 & 300 & 310 & 320 & 330 \\
\hline & Sectional area, $A\left(m^{2}\right)$ & 6.42 & 6.87 & 7.39 & 7.95 & 8.59 & 9.26 \\
\hline \multirow{4}{*}{12} & Thickness of top flange, $t_{t f}(\mathrm{~mm})$ & 255 & 255 & 255 & 258 & 280 & 300 \\
\hline & Thickness of bottom flange, $t_{b f}(\mathrm{~mm})$ & 300 & 300 & 305 & 310 & 315 & 320 \\
\hline & Thickness of web, $t_{w}(\mathrm{~mm})$ & 300 & 300 & 320 & 330 & 340 & 340 \\
\hline & Sectional area, $A\left(\mathrm{~m}^{2}\right)$ & 6.17 & 6.54 & 7.09 & 7.63 & 8.4 & 9.05 \\
\hline \multirow{4}{*}{14} & Thickness of top flange, $t_{t f}(\mathrm{~mm})$ & - & 320 & 360 & 360 & 360 & 360 \\
\hline & Thickness of bottom flange, $t_{b f}(\mathrm{~mm})$ & - & 360 & 390 & 420 & 445 & 490 \\
\hline & Thickness of web, $t_{w}(\mathrm{~mm})$ & - & 400 & 420 & 440 & 470 & 490 \\
\hline & Sectional area, $A\left(m^{2}\right)$ & - & 7.68 & 8.77 & 9.49 & 10.31 & 11.18 \\
\hline \multirow{4}{*}{16} & Thickness of top flange, $t_{t f}(\mathrm{~mm})$ & - & - & 300 & 400 & - & - \\
\hline & Thickness of bottom flange, $t_{b f}(\mathrm{~mm})$ & - & - & 480 & 650 & - & - \\
\hline & Thickness of web, $t_{w}(\mathrm{~mm})$ & - & - & 360 & 440 & - & - \\
\hline & Sectional area, $A\left(\mathrm{~m}^{2}\right)$ & - & - & 7.93 & 10.51 & - & - \\
\hline
\end{tabular}


Table 6 Stresses $\left(\mathrm{N} / \mathrm{mm}^{2}\right)$ for different cross-sections of single-cell

\begin{tabular}{|c|c|c|c|c|c|c|c|}
\hline \multirow[b]{2}{*}{$L / d$} & \multirow[b]{2}{*}{$L(m)$} & \multicolumn{2}{|c|}{ Single-cell } & \multicolumn{2}{|c|}{ Double-cell } & \multirow{2}{*}{$\begin{array}{c}\text { Permissible } \\
\text { compressive } \\
\text { stress }\left(\sigma_{C}\right)\end{array}$} & \multirow{2}{*}{$\begin{array}{c}\text { Permissible } \\
\text { tensile stress } \\
\left(\sigma_{T}\right)\end{array}$} \\
\hline & & $\sigma_{c t}$ & $\sigma_{t b}$ & $\sigma_{c t}$ & $\sigma_{t b}$ & & \\
\hline \multirow{6}{*}{10} & 25 & 7.352 & 121.560 & 7.362 & 121.726 & 13.33 & 240 \\
\hline & 30 & 7.521 & 124.355 & 7.316 & 120.965 & 13.33 & 240 \\
\hline & 35 & 7.734 & 127.877 & 7.755 & 128.224 & 13.33 & 240 \\
\hline & 40 & 7.961 & 131.630 & 8.215 & 135.830 & 13.33 & 240 \\
\hline & 45 & 8.206 & 135.681 & 8.695 & 143.766 & 13.33 & 240 \\
\hline & 50 & 8.544 & 141.269 & 9.256 & 153.042 & 13.33 & 240 \\
\hline \multirow{6}{*}{12} & 25 & 8.954 & 148.048 & 8.668 & 143.320 & 13.33 & 240 \\
\hline & 30 & 9.448 & 156.216 & 9.172 & 151.653 & 13.33 & 240 \\
\hline & 35 & 9.461 & 156.431 & 9.578 & 158.366 & 13.33 & 240 \\
\hline & 40 & 9.736 & 160.978 & 10.065 & 166.418 & 13.33 & 240 \\
\hline & 45 & 9.694 & 160.284 & 10.692 & 176.785 & 13.33 & 240 \\
\hline & 50 & 10.118 & 167.294 & 11.291 & 186.689 & 13.33 & 240 \\
\hline \multirow{5}{*}{14} & 30 & 10.138 & 167.625 & 10.813 & 178.786 & 13.33 & 240 \\
\hline & 35 & 10.668 & 176.388 & 11.300 & 186.838 & 13.33 & 240 \\
\hline & 40 & 11.099 & 183.515 & 11.613 & 192.013 & 13.33 & 240 \\
\hline & 45 & 11.640 & 192.460 & 12.059 & 199.388 & 13.33 & 240 \\
\hline & 50 & 12.406 & 205.125 & 12.479 & 206.332 & 13.33 & 240 \\
\hline \multirow{2}{*}{16} & 35 & 12.007 & 198.528 & 12.055 & 199.322 & 13.33 & 240 \\
\hline & 40 & 12.615 & 208.581 & 12.629 & 208.812 & 13.33 & 240 \\
\hline
\end{tabular}

Table 7 Vertical deflection for different cross-sections of single-cell

\begin{tabular}{|c|c|c|c|c|}
\hline \multirow{2}{*}{$L / d$} & \multirow{2}{*}{$L(m)$} & \multicolumn{2}{|c|}{ Maximum deflection ( $\mathrm{mm}$ ) } & \multirow{2}{*}{ Permissible deflection ( $\mathrm{mm}$ ) } \\
\hline & & Single-cell & Double-cell & \\
\hline \multirow{6}{*}{10} & 25 & 14.44 & 12.20 & 31.25 \\
\hline & 30 & 17.01 & 15.30 & 37.50 \\
\hline & 35 & 19.40 & 18.30 & 43.75 \\
\hline & 40 & 22.15 & 21.60 & 50.00 \\
\hline & 45 & 25.16 & 25.10 & 56.25 \\
\hline & 50 & 28.77 & 29.30 & 62.50 \\
\hline \multirow{6}{*}{12} & 25 & 19.88 & 17.20 & 31.25 \\
\hline & 30 & 23.34 & 21.00 & 37.50 \\
\hline & 35 & 26.37 & 24.90 & 43.75 \\
\hline & 40 & 30.15 & 29.40 & 50.00 \\
\hline & 45 & 35.16 & 34.10 & 56.25 \\
\hline & 50 & 38.80 & 39.60 & 62.50 \\
\hline \multirow{5}{*}{14} & 30 & 27.33 & 26.10 & 37.50 \\
\hline & 35 & 31.78 & 31.10 & 43.75 \\
\hline & 40 & 37.20 & 36.60 & 50.00 \\
\hline & 45 & 43.51 & 43.00 & 56.25 \\
\hline & 50 & 51.01 & 50.20 & 62.50 \\
\hline \multirow{2}{*}{16} & 35 & 41.68 & 40.10 & 43.75 \\
\hline & 40 & 48.55 & 47.20 & 50.00 \\
\hline
\end{tabular}


After finalizing the section by trial and error method, a comparison is made between the values obtained by the similitude, and the trial and error methods, as presented in Table 8 . The values of the area and the moment of inertia required for different box sections, obtained by the trial and error method, are much lower than those given by the similitude procedure. Hence, the properties obtained by the trial and error method and based on the provisions of IRC: 21 and Rajagopalan [39] are used in the present study. The above properties are mentioned below:

1. The span of the box-girder bridge should not be less than $25 \mathrm{~m}$,

2. The span-depth ratio should be around 17-18 for RC bridge,

3. Cantilever arm length is equal to 0.45 times the distance between webs,

4. The minimum soffit slab thickness should be $1 / 20$ times the distance between webs.

Table 8 Comparison of cross-sectional properties

\begin{tabular}{|c|c|c|c|c|}
\hline$L(m)$ & $\begin{array}{c}A\left(\mathrm{~m}^{2}\right) \\
(\text { similitude) }\end{array}$ & $\begin{array}{c}A\left(\mathrm{~m}^{2}\right) \\
\text { (trial and error) }\end{array}$ & $\begin{array}{c}I\left(\mathrm{~m}^{4}\right) \\
\text { (similitude) }\end{array}$ & $\begin{array}{c}I\left(\mathrm{~m}^{4}\right) \\
\text { (trial and error) }\end{array}$ \\
\hline 25 & 6.42 & 6.42 & 6.80 & 6.80 \\
\hline 30 & 9.25 & 6.82 & 14.10 & 10.35 \\
\hline 35 & 12.58 & 7.37 & 26.13 & 15.16 \\
\hline 40 & 16.43 & 7.95 & 44.58 & 21.16 \\
\hline 45 & 20.80 & 8.57 & 71.40 & 28.48 \\
\hline 50 & 25.68 & 9.24 & 108.83 & 37.26 \\
\hline
\end{tabular}

\section{MODELLING}

The modelling of any structure can be done either in two-dimension or three-dimension, but it must be done in three-dimension to assess the loads' effect on the structure. In the present study, the modelling and analysis of box-girder bridges are carried out with a finite element method following the steps depicted in Figure 2. The assumptions considered for the modelling of the box-girder bridge are:

- Material is elastic, isotropic and homogeneous,

- The deck rests on two longitudinal webs and is simply supported,

- There are two end diaphragm in all the models,

- The dead weight effect of kerb and footpath are neglected in all the models, and

- Both the dead and live loads are taken as service loads, and other loads such as wind, seismic, snow, creep, thermal and fatigue are neglected. 


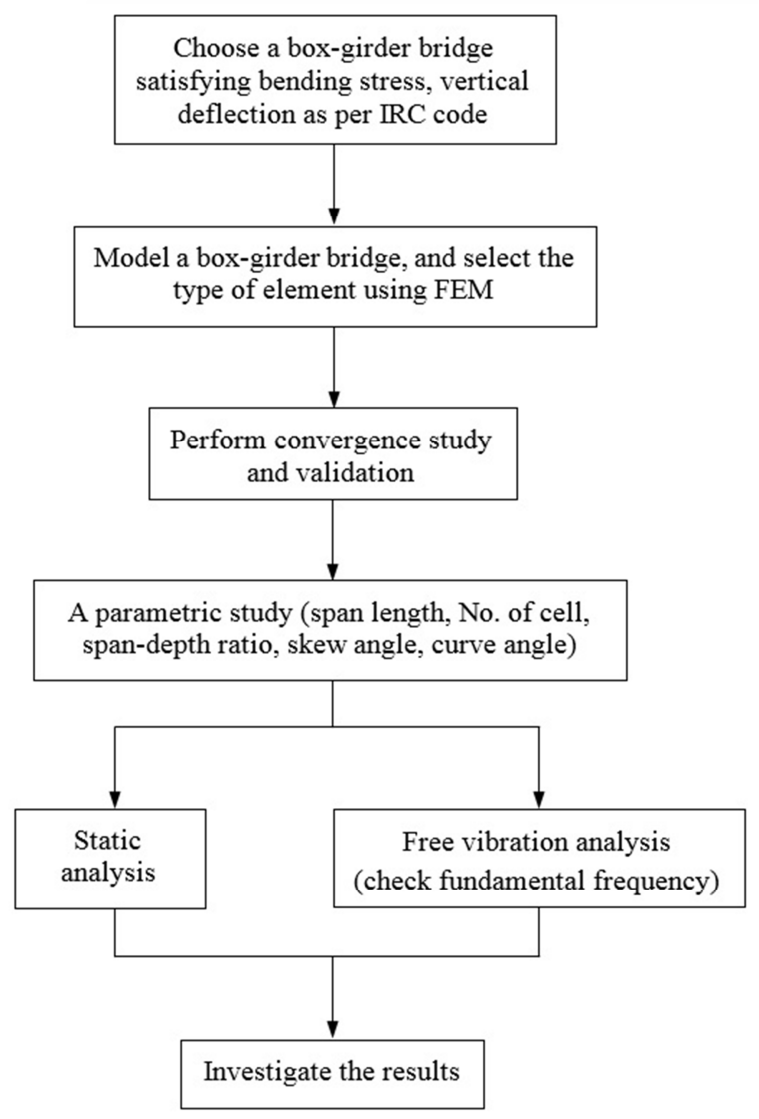

Fig. 2 Flow diagram of the study

The bridges are modelled according to the cross-sections listed in Tables 4 and 5 . The other relevant dimensions considered are: total width $=11.5 \mathrm{~m}$ (consisting of roadway $=7.5 \mathrm{~m}$; kerb $=0.5 \mathrm{~m}$ on both sides; footpath $=1.5 \mathrm{~m}$ on both sides of the deck). Figure 3 shows the crosssection of both single-cell and double-cell box-girder bridges. The various material properties used in the study are in Table 9.

Table 9 Material Properties

\begin{tabular}{|l|c|c|}
\hline \multicolumn{1}{|c|}{ Material properties } & Concrete & Steel \\
\hline Characteristic strength $(\mathrm{MPa})$ & 40 & 77 \\
\hline Density $\left(\mathrm{kN} / \mathrm{m}^{3}\right)$ & 25 & $2 \times 10^{8}$ \\
\hline Modulus of elasticity $\left(\mathrm{kN} / \mathrm{m}^{2}\right)$ & $3.16 \times 10^{7}$ & $7.69 \times 10^{7}$ \\
\hline Modulus of rigidity $(\mathrm{MPa})$ & $1.31 \times 10^{7}$ & 500 \\
\hline Yield strength $(\mathrm{MPa})$ & - & 545 \\
\hline Ultimate tensile strength $(\mathrm{MPa})$ & - & - \\
\hline
\end{tabular}




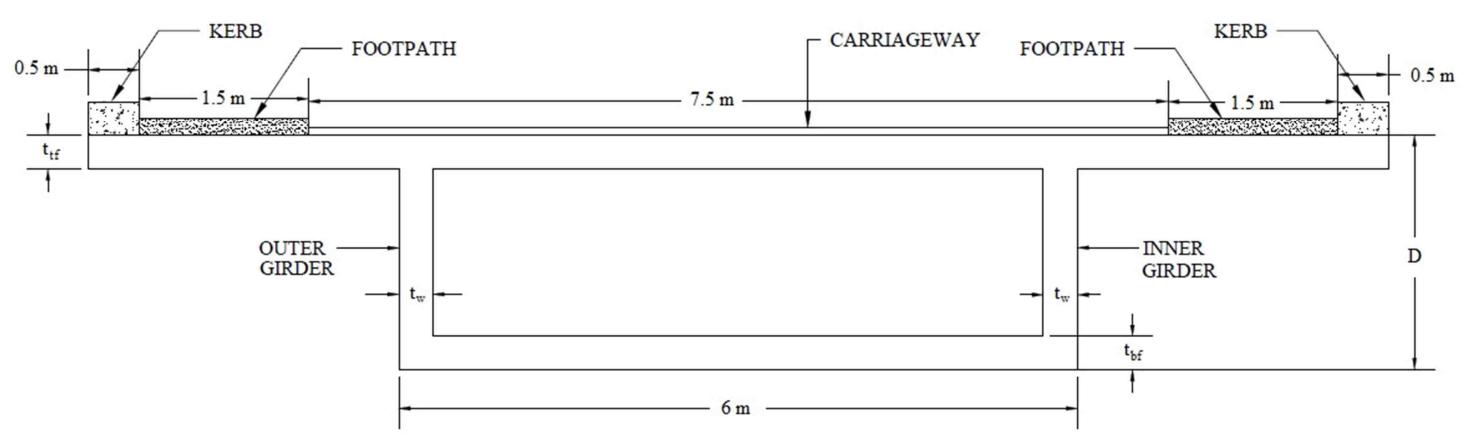

(a) Single-cell box-girder bridge

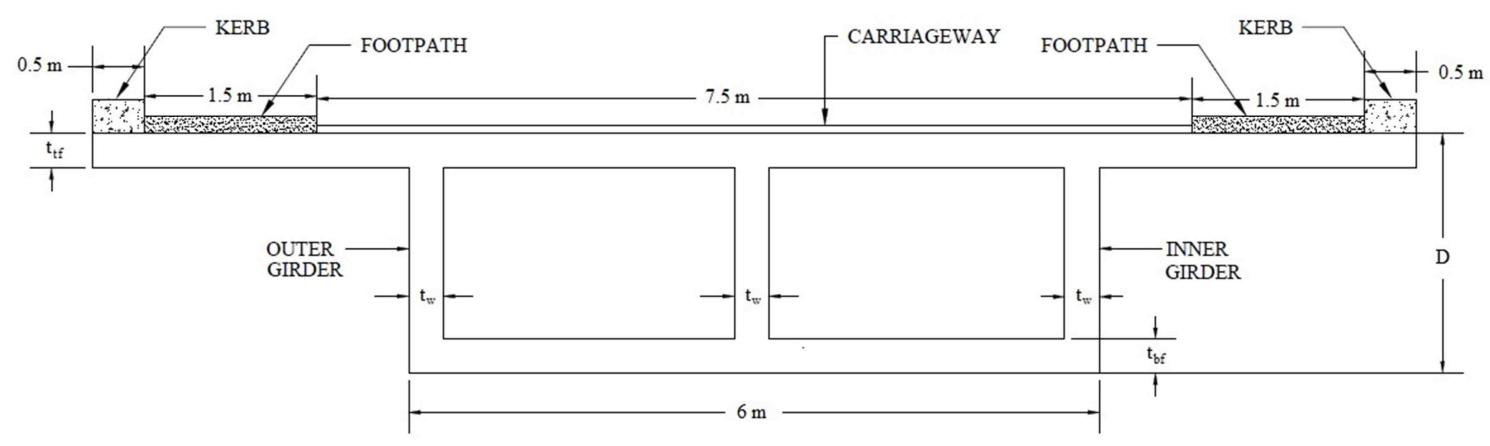

(b) Double-cell box-girder bridge

Fig. 3 Cross-section of the box-girder bridges

The CSiBridge considers the embedded reinforcement based on different codes of practices. The option for inclusion of the minimum amount of reinforcement specifications and its placement details conforming to clause 16.5.1.1 of IRC: 112 is available in CSiBridge, and thus the same is adopted for the study. The simply supported boundary condition is employed to restrain the bridges, and for that, two roller bearings on one end and two pin/hinge bearings on the other end are considered, as shown in Figure 4. For roller support, only one translation in the bridge's longitudinal direction is allowed. For pin support, all the three translations in longitudinal, transverse and vertical directions of the bridge are restrained.

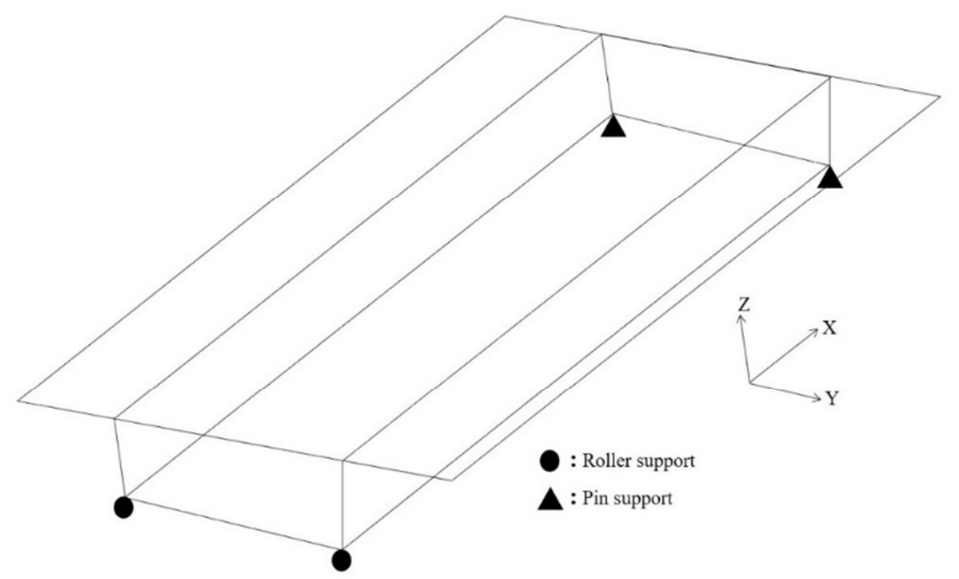

Fig. 4 Boundary condition 
For discretizing the bridge, four noded shell element having six degrees of freedom (three translations and three rotations) at each node is used. Figure 5 shows the discretized finite element models of box-girder bridges captured in the modelling process.

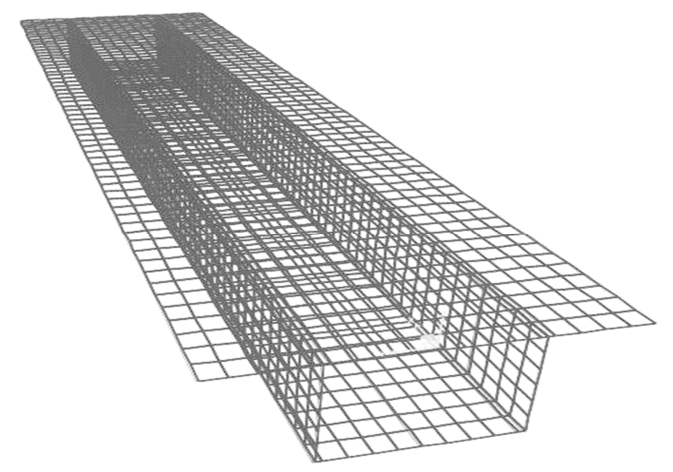

Fig. 5 Shell element of straight box-girder bridge

The primary loads considered in the present study are dead load, i.e., self-weight of the bridge deck and live load as per IRC: 6 [40]. The dead load is calculated for the different cross-sections of single and double cell box-girder bridges using the volume and the density of materials used. The live loads are complex, so Codal provisions are used for their application on the bridges. The analysis of live loads is considered according to IRC: 6 . Following three types of loadings are available for permanent road bridges according to IRC: 6 .

1. IRC Class 70R loading:
a) Track loading
b) Wheel loading

2. IRC Class AA loading:
a) Track loading
b) Wheel loading

\section{IRC Class A loading}

The stresses and deflection of a single-cell box-girder bridge are determined for both dead and live loads. The maximum values of vertical deflection and the stresses in a single-cell boxgirder bridge for different IRC loads are presented in Tables 10 and 11, respectively. All Indian loadings Class-70R track \& wheel loads, Class-AA track \& wheel loads, and Class-A load are considered to analyse all the bridge models, but the obtained forces and deflection are found to be maximum for Class-70R track load. Thus, in the present study, only IRC Class 70-R track load is considered for two lanes bridges, as per IRC: 6 . 
Table 10 Vertical deflection due to different live loads for a single-cell box-girder bridge

\begin{tabular}{|c|c|c|c|c|c|c|c|}
\hline$L / d$ & $L(m)$ & $\begin{array}{c}\text { Class } 70-R \text { track } \\
\text { vehicle }\end{array}$ & $\begin{array}{c}\text { Class } 70-R \\
\text { wheel }\end{array}$ & $\begin{array}{l}\text { Class } A A \\
\text { track } \\
\end{array}$ & $\begin{array}{c}\text { Class } A A \\
\text { wheel }\end{array}$ & $\begin{array}{c}\text { Class A } \\
\text { wheel }\end{array}$ & $\begin{array}{c}\text { Permissible } \\
\text { limit }\end{array}$ \\
\hline \multirow{6}{*}{10} & 25 & 14.44 & 7.072 & 6.51 & 5.93 & 6.87 & 31.25 \\
\hline & 30 & 17.01 & 9.31 & 8.64 & 7.99 & 9.18 & 37.50 \\
\hline & 35 & 19.40 & 11.71 & 10.98 & 10.31 & 11.64 & 43.75 \\
\hline & 40 & 22.15 & 14.49 & 13.71 & 13.01 & 14.48 & 50.00 \\
\hline & 45 & 25.16 & 17.56 & 16.77 & 16.05 & 17.60 & 56.25 \\
\hline & 50 & 28.77 & 21.19 & 20.36 & 19.62 & 21.25 & 62.50 \\
\hline \multirow{6}{*}{12} & 25 & 19.88 & 9.85 & 9.08 & 8.25 & 9.59 & 31.25 \\
\hline & 30 & 23.34 & 12.91 & 11.99 & 11.08 & 12.75 & 37.50 \\
\hline & 35 & 26.37 & 16.09 & 15.11 & 14.15 & 16.03 & 43.75 \\
\hline & 40 & 30.15 & 19.97 & 18.93 & 17.93 & 19.99 & 50.00 \\
\hline & 45 & 34.83 & 23.96 & 22.91 & 21.90 & 24.04 & 56.25 \\
\hline & 50 & 38.80 & 28.99 & 27.92 & 26.87 & 29.13 & 62.50 \\
\hline \multirow{5}{*}{14} & 30 & 27.33 & 16.82 & 15.89 & 14.83 & 16.70 & 37.50 \\
\hline & 35 & 31.78 & 21.73 & 20.75 & 19.67 & 21.73 & 43.75 \\
\hline & 40 & 37.20 & 27.09 & 26.03 & 24.91 & 27.17 & 50.00 \\
\hline & 45 & 43.51 & 33.31 & 32.19 & 32.01 & 33.47 & 56.25 \\
\hline & 50 & 51.01 & 49.87 & 39.31 & 38.27 & 40.86 & 62.50 \\
\hline \multirow{2}{*}{16} & 35 & 41.68 & 27.76 & 26.41 & 24.89 & 27.78 & 43.75 \\
\hline & 40 & 48.55 & 36.57 & 35.32 & 33.92 & 36.70 & 50.00 \\
\hline
\end{tabular}

Table 11 Bending compressive stress (MPa) due to different live loads for a single-cell box-girder bridge

\begin{tabular}{|c|c|c|c|c|c|c|c|}
\hline$L / d$ & $L(m)$ & $\begin{array}{c}\text { Class } 70-R \text { track } \\
\text { vehicle }\end{array}$ & $\begin{array}{c}\text { Class } 70-R \\
\text { wheel }\end{array}$ & $\begin{array}{l}\text { Class AA } \\
\text { track } \\
\end{array}$ & $\begin{array}{c}\text { Class AA } \\
\text { wheel } \\
\end{array}$ & $\begin{array}{l}\text { Class A } \\
\text { wheel } \\
\end{array}$ & $\begin{array}{c}\text { Permissible } \\
\text { limit }\end{array}$ \\
\hline \multirow{6}{*}{10} & 25 & 7.13 & 3.99 & 3.86 & 3.48 & 3.91 & 13.33 \\
\hline & 30 & 7.57 & 4.58 & 4.42 & 4.05 & 4.52 & 13.33 \\
\hline & 35 & 7.73 & 5.02 & 4.84 & 4.51 & 4.99 & 13.33 \\
\hline & 40 & 7.96 & 5.48 & 5.29 & 4.98 & 5.47 & 13.33 \\
\hline & 45 & 8.21 & 5.93 & 5.74 & 5.48 & 5.94 & 13.33 \\
\hline & 50 & 8.54 & 6.43 & 6.25 & 5.98 & 6.45 & 13.33 \\
\hline \multirow{6}{*}{12} & 25 & 8.95 & 4.95 & 4.77 & 4.29 & 4.85 & 13.33 \\
\hline & 30 & 9.45 & 5.65 & 5.43 & 4.97 & 5.57 & 13.33 \\
\hline & 35 & 9.48 & 6.08 & 5.85 & 5.43 & 6.04 & 13.33 \\
\hline & 40 & 9.73 & 6.63 & 6.40 & 6.01 & 6.62 & 13.33 \\
\hline & 45 & 9.88 & 6.97 & 6.74 & 6.39 & 6.98 & 13.33 \\
\hline & 50 & 10.11 & 7.58 & 7.36 & 7.04 & 7.61 & 13.33 \\
\hline \multirow{5}{*}{14} & 30 & 10.13 & 6.39 & 6.17 & 5.71 & 6.30 & 13.33 \\
\hline & 35 & 10.67 & 7.29 & 7.06 & 6.64 & 7.25 & 13.33 \\
\hline & 40 & 11.08 & 7.99 & 7.76 & 7.37 & 7.98 & 13.33 \\
\hline & 45 & 11.61 & 8.77 & 8.53 & 8.17 & 8.79 & 13.33 \\
\hline & 50 & 12.41 & 10.91 & 9.35 & 9.14 & 9.74 & 13.33 \\
\hline \multirow{2}{*}{16} & 35 & 12.01 & 7.96 & 7.68 & 7.18 & 7.91 & 13.33 \\
\hline & 40 & 12.61 & 9.32 & 9.07 & 8.65 & 9.31 & 13.33 \\
\hline
\end{tabular}




\section{ANALYSIS}

The structural response of the box-girder bridges is evaluated to assess its behavior. The validation of present results has been done to check the suitability of the adopted methodology, presented in the literature by Agarwal et al. [35]. Here, the analyses are divided into two parts, i.e., static analysis and free vibration analysis. For static analysis, both dead and live loads are applied to the bridges to assess the bridge's response. The free vibration analysis is performed to determine the deck's natural frequencies.

\subsection{STATIC ANALYSIS}

A model of a simply supported single-cell skew-curved RC box-girder bridge is studied, and the results are available in the literature published by the present authors [35]. The relevant deck data considered for the study are: Span $=45 \mathrm{~m}$; Total width $=11.5 \mathrm{~m}$, consisting of roadway = $7.5 \mathrm{~m}$, Kerb $=0.5 \mathrm{~m}$ on both sides, and Footpath $=1.5 \mathrm{~m}$ on both sides. The thickness of the top and bottom flanges are $0.30 \mathrm{~m}$ and $0.36 \mathrm{~m}$, respectively, and the thickness of the web is $0.38 \mathrm{~m}$. The results obtained from the proposed methodology give satisfactory results. In the study, all Indian loadings are considered to analyse the bridge models, but only Class 70-R track load is taken for illustration purposes as it produces the maximum forces and deflection. Class 70-R track load and its position on the bridge are shown in Figure 6. The maximum bending moment, shear force, torsional moment and vertical deflection in both the webs of a skewcurved bridge under both dead and live loads are investigated with varying skew and curve angles. Further, the different models of a single-cell RC box-girder bridge investigated to determine the bridge's maximum deflection, presented in Table 12 and Figure 7 include: straight $\left(\alpha=0^{\circ}\right.$ and $\left.\theta=0^{\circ}\right)$, curved $\left(\alpha=48^{\circ}\right.$ and $\left.\theta=0^{\circ}\right)$, skew $\left(\alpha=0^{\circ}\right.$ and $\left.\theta=60^{\circ}\right)$, and skewcurved $\left(\alpha=48^{\circ}\right.$ and $\left.\theta=60^{\circ}\right)$. It is found that the results almost converge after the mesh size of $100 \mathrm{~mm}$ or less. The vertical deflection of the skew bridge is much lesser than any other bridge (straight bridge, curved bridge and skew-curved bridge). The vertical deflection of the skew bridge is about $18 \%$ lesser than the straight bridge, $68 \%$ lesser than the curved bridge and $40 \%$ lesser than the skew-curved bridge.
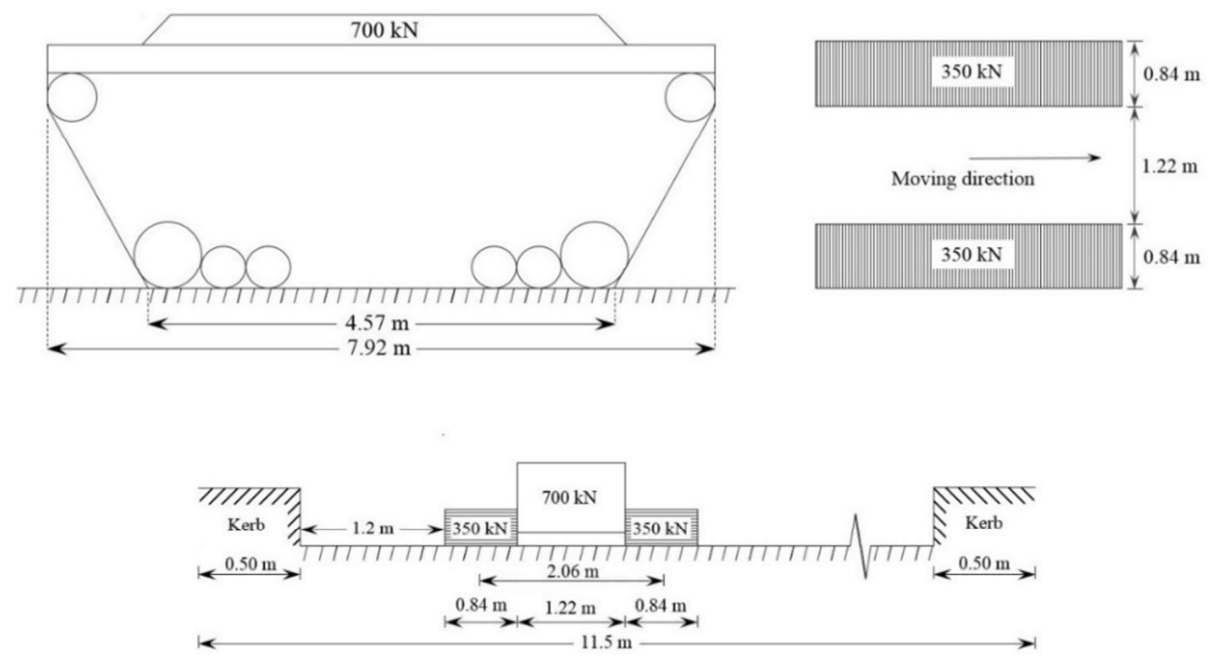

Fig. 6 IRC Class 70-R track loading 
Table 12 Maximum vertical deflection $(\mathrm{mm})$ of bridges

\begin{tabular}{|c|c|c|c|c|}
\hline Mesh Size $(\mathrm{mm})$ & Straight & $\begin{array}{c}\text { Skew } \\
\left(\theta=60^{\circ}\right)\end{array}$ & $\begin{array}{c}\text { Curved } \\
\left(\alpha=48^{\circ}\right)\end{array}$ & $\begin{array}{c}\text { Skew-curved } \\
\left(\theta=60^{\circ} \& \alpha=48^{\circ}\right)\end{array}$ \\
\hline 500 & 15.52 & 11.24 & 53.62 & 25.67 \\
\hline 450 & 17.85 & 13.57 & 55.12 & 27.56 \\
\hline 400 & 18.95 & 14.36 & 56.95 & 28.68 \\
\hline 350 & 20.85 & 15.89 & 57.59 & 31.57 \\
\hline 300 & 21.25 & 16.98 & 59.84 & 32.49 \\
\hline 250 & 22.85 & 18.65 & 60.12 & 33.52 \\
\hline 200 & 24.85 & 19.12 & 61.54 & 34.21 \\
\hline 150 & 25.10 & 19.58 & 62.45 & 34.44 \\
\hline 100 & 25.16 & 20.66 & 63.88 & 34.45 \\
\hline 90 & 25.16 & 20.67 & 63.88 & 34.45 \\
\hline
\end{tabular}

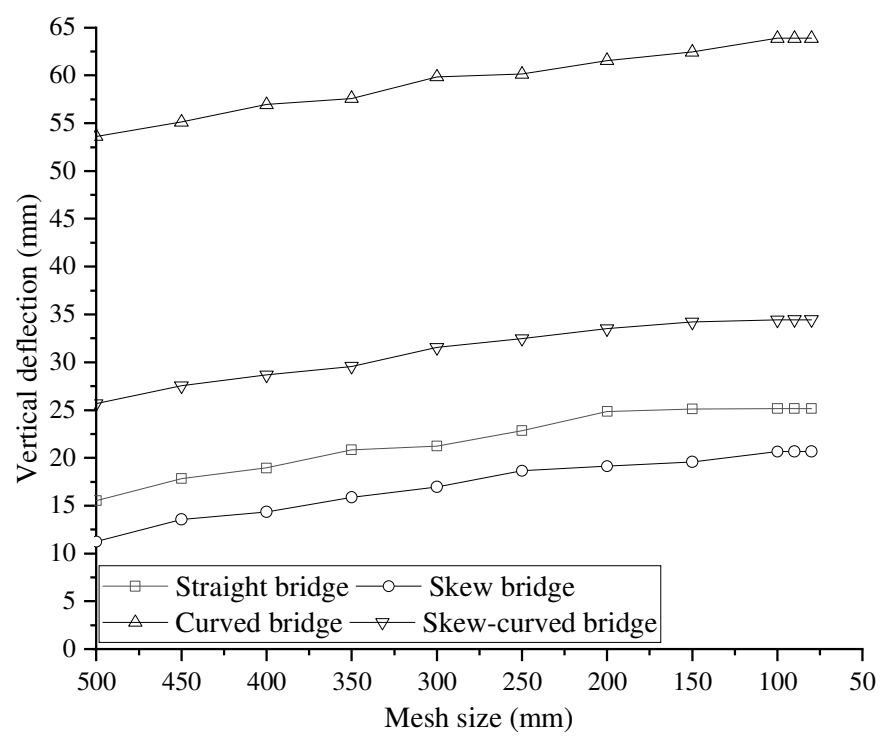

Fig. 7 Maximum vertical deflection of different box-girder bridges

A comparative study has been made between IRC class-70R track load and EN LM-1 [Clause no. 4.3.2, EN 1991-2 [41]] load for a straight box-girder bridge. Also, the effect of span length on bending moment, shear force, torsional moment and vertical deflection is investigated. The cross-section, material properties, and boundary and loading conditions are already described in section 3. The loading position is considered the same in both cases. Figure 8 shows the variation of bending moment, shear force, torsional moment and vertical deflection with span length for different loadings. It is observed that the forces and deflection are increasing nonlinearly with the span length in both the load cases. The rate of the increment is more in the case of Class-70R track load. When span length varies from $25 \mathrm{~m}$ to $50 \mathrm{~m}$, the bending moment becomes about 2.0 times in outer web and 1.8 times in inner web, under IRC class-70R track load, while it becomes approximately 2.7 times in both outer and inner webs, under EN LM-1 load. Similarly, the shear force in both the webs is about 1.06 times under IRC class-70R track load, while it becomes about 1.28 and 1.36 times in outer and inner webs, respectively, under 
EN LM-1 load. Likewise, the vertical deflection becomes 1.21 and 1.08 times in outer and inner web, respectively, under IRC class-70R track load, while it becomes about double in both the webs, under EN LM-1 load. There is no significant change in the torsional moment in any load case in both webs of a bridge. The torsional moment increases slightly or remains almost constant with the increase in span length under IRC class-70R track load, while it becomes about 1.3 times in both the webs, under EN LM-1 load, when the span varies from $25 \mathrm{~m}$ to 50 $m$. This study concludes that the IRC class-70R track load is more severe than the EN LM-1 load. However, considering the variation in results, one may use the EN LM-1 loads for analysing the box-girder bridges following the proposed methodology.

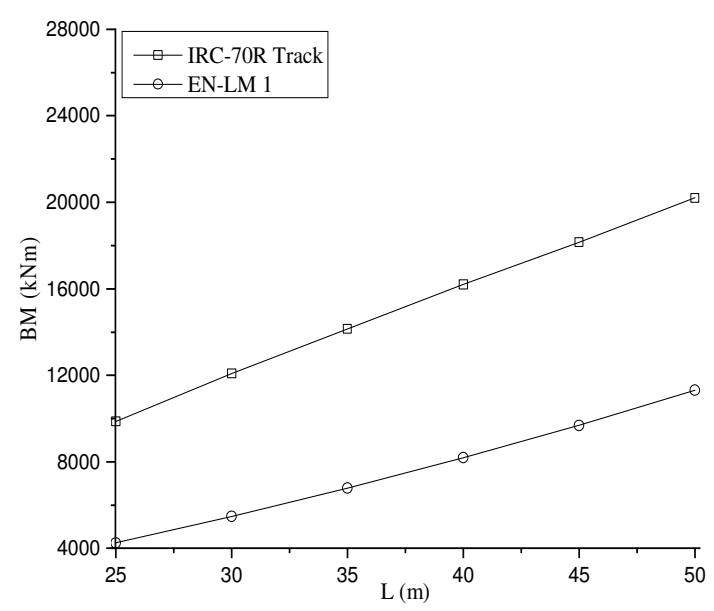

i) Outer web

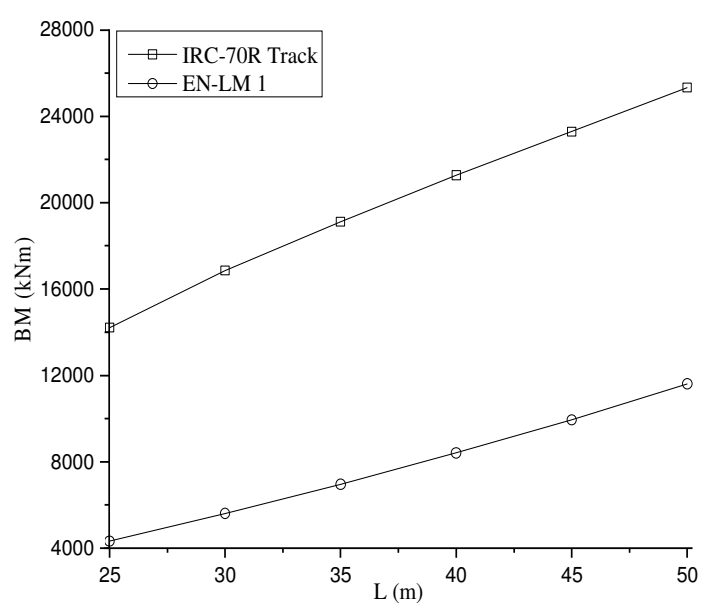

ii) Inner web

a) Variation of Bending moment

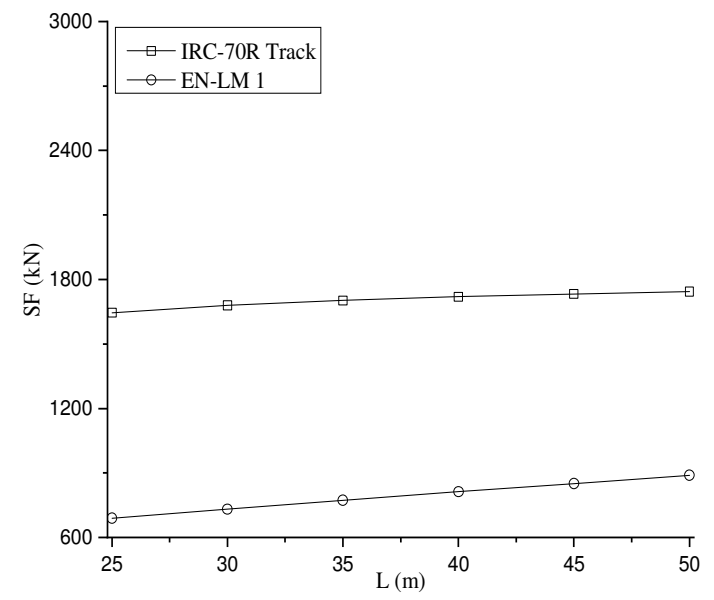

i) Outer web

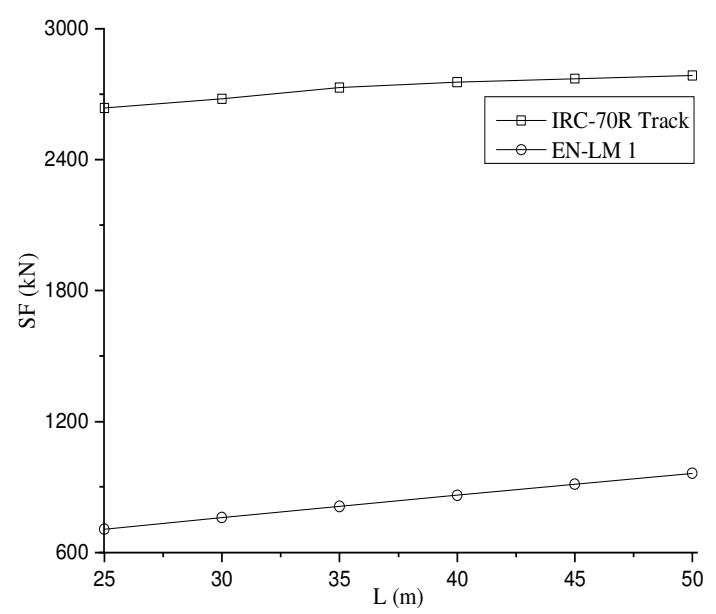

ii) Inner web

b) Variation of shear force 


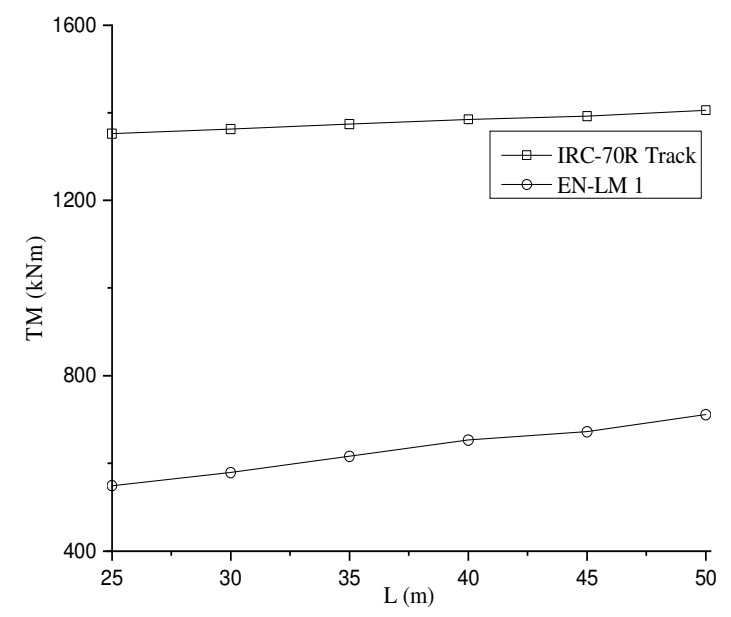

i) Outer web

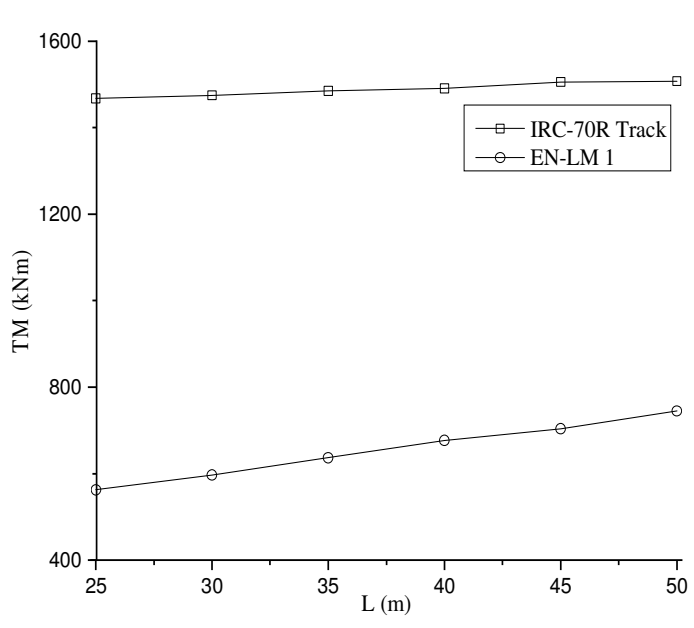

ii) Inner web

c) Variation of torsional moment

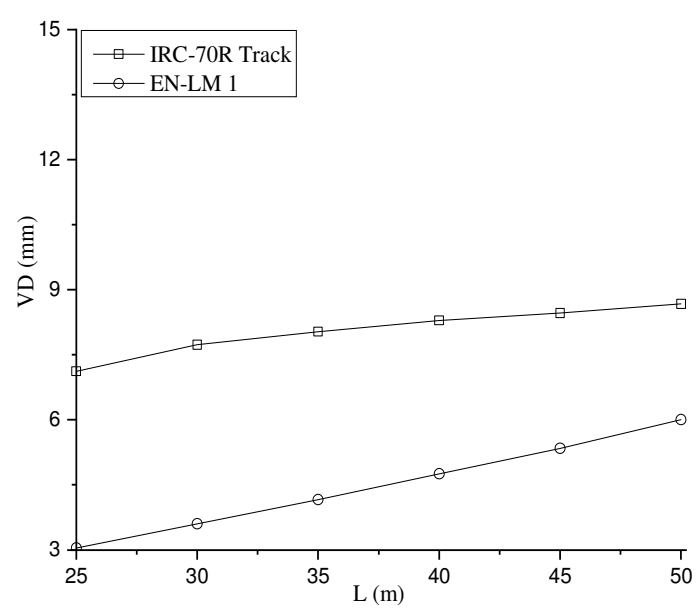

i) Outer web

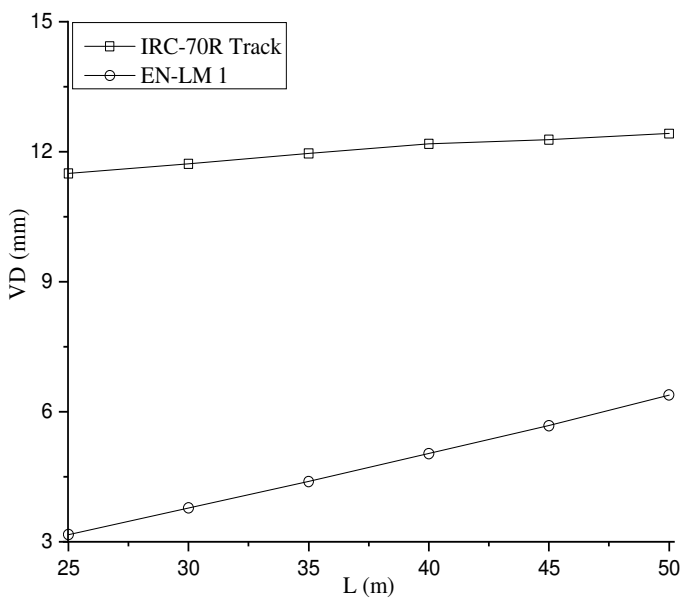

ii) Inner web

d) Variation of vertical deflection

Fig. 8 Variation of forces and deflection with span length for different loadings

\subsection{FREE VIBRATION ANALYSIS}

The vibration amplitude in concrete bridges is so small that it practically does not pose any problem, thereby not affecting the traffic and the people. Therefore, there are no limitations to the vibration. The natural frequencies and the mode shapes of vibration depend upon the whole structural system, i.e., road characteristics, the material used, cross-sectional properties, etc. The bridges' fundamental frequency range lies within a range of about 1 to 20 cycles/second.

The bridge deck's vibration analysis specifications are presented within Lenzen's criteria [42]. The following steps are followed for the vibration analysis of different bridge decks:

i) Estimate the maximum deflection under DL 
Span $=25 m, L / d=10$

For, Concrete characteristic compressive strength, $40 \mathrm{MPa}$,

$$
E=5700 \sqrt{40}=36050 \mathrm{~N} / \mathrm{mm}^{2}=36.050 \times 10^{6} \mathrm{kN} / \mathrm{m}^{2}, I=6.80 \mathrm{~m}^{4}
$$

Therefore, Maximum deflection, $\delta=\frac{W L^{3}}{48 E I}=\frac{200 \times 25^{3}}{48 \times 36.050 \times 10^{6} \times 6.80}=0.27 \mathrm{~mm}$

ii) Natural frequency of vibration:

$$
\begin{aligned}
N_{f} & =\frac{2}{L^{2}} \sqrt{\frac{E I g}{w_{d}}} \text { cycles } / \text { second } \\
= & \frac{2}{25^{2}} \sqrt{\frac{36.050 \times 10^{6} \times 9.81}{25 \times 6.42}} \\
= & 12.39 \text { cycles } / \text { second }
\end{aligned}
$$

iii) $N_{f}>4$ cycles per second, so $\Delta=0.40 \delta=0.40 \times 0.27=0.11 \mathrm{~mm}$

iv) Acceleration $a=40 \Delta N_{f}^{2} \mathrm{~mm} / \mathrm{sec}^{2}$

$$
a=40 \times 0.11 \times 12.39^{2}=651.96 \mathrm{~mm} / \mathrm{sec}^{2}
$$

v) Ensure that the product $a \Delta \ngtr 3226 \mathrm{~mm} / \mathrm{sec}^{2}$

$$
651.96 \times 0.11=71.71 \ngtr 3226 \mathrm{~mm} / \mathrm{sec}^{2}
$$

vi) Vibration characteristic is found from Lenzen's criteria based on the values of $N_{f}$ and $\Delta$.

Similarly, the vibration characteristic for different spans and the span-depth ratio is calculated and presented in Table 13. It is found that adopted cross-sections of box-girder bridges satisfy the vibration criteria and lie in a slightly perceptible zone.

After finalizing the cross-section, the free vibration analysis of different models of a simply supported single-cell RC box-girder bridge is carried out. The cross-section, material properties, and boundary conditions are kept the same as in the static analysis. The different models, i.e., straight $\left(\alpha=0^{\circ}\right.$ and $\left.\theta=0^{\circ}\right)$, curved $\left(\alpha=48^{\circ}\right.$ and $\left.\theta=0^{\circ}\right)$, skew $\left(\alpha=0^{\circ}\right.$ and $\left.\theta=60^{\circ}\right)$, and skew-curved $\left(\alpha=48^{\circ}\right.$ and $\left.\theta=60^{\circ}\right)$, are investigated, and the results are presented in Table 14 and Figure 9. It is observed that the results nearly converge after the mesh size of $100 \mathrm{~mm}$ or less. The fundamental frequency of skew-curved bridges is more than straight, skew and curved bridges for about $14 \%, 10 \%$, and $13 \%$, respectively. 
Table 13 Vibration criteria in box-girder bridge

\begin{tabular}{|c|c|c|c|c|c|c|c|c|c|}
\hline$L / d$ & $\begin{array}{c}L \\
(m)\end{array}$ & $\begin{array}{c}A \\
\left(m^{2}\right)\end{array}$ & $\begin{array}{c}I \\
\left(m^{4}\right)\end{array}$ & $\begin{array}{c}\delta \\
(\mathrm{mm})\end{array}$ & $N_{f}($ cycle $/ \mathrm{sec})$ & $\Delta(\mathrm{mm})$ & $A\left(\mathrm{~mm} / \mathrm{sec}^{2}\right)$ & $\begin{array}{c}\text { Safel } \\
\text { Unsafe }\end{array}$ & Zone \\
\hline \multirow{6}{*}{10} & 25 & 6.42 & 6.80 & 0.27 & 12.39 & 0.11 & 651.96 & Safe & $\begin{array}{c}\text { Slightly } \\
\text { perceptible }\end{array}$ \\
\hline & 30 & 6.82 & 10.35 & 0.30 & 10.30 & 0.12 & 511.44 & Safe & $\begin{array}{c}\text { Slightly } \\
\text { perceptible }\end{array}$ \\
\hline & 35 & 7.37 & 15.16 & 0.33 & 8.81 & 0.13 & 405.66 & Safe & $\begin{array}{c}\text { Slightly } \\
\text { perceptible }\end{array}$ \\
\hline & 40 & 7.95 & 21.16 & 0.35 & 7.67 & 0.14 & 329.06 & Safe & $\begin{array}{c}\text { Slightly } \\
\text { perceptible }\end{array}$ \\
\hline & 45 & 8.57 & 28.48 & 0.37 & 6.77 & 0.15 & 271.33 & Safe & $\begin{array}{c}\text { Slightly } \\
\text { perceptible }\end{array}$ \\
\hline & 50 & 9.24 & 37.26 & 0.39 & 6.04 & 0.16 & 226.49 & Safe & $\begin{array}{c}\text { Slightly } \\
\text { perceptible }\end{array}$ \\
\hline \multirow{6}{*}{12} & 25 & 6.17 & 4.49 & 0.40 & 10.27 & 0.16 & 678.38 & Safe & $\begin{array}{c}\text { Slightly } \\
\text { perceptible }\end{array}$ \\
\hline & 30 & 6.52 & 6.84 & 0.46 & 8.56 & 0.18 & 534.97 & Safe & $\begin{array}{c}\text { Slightly } \\
\text { perceptible }\end{array}$ \\
\hline & 35 & 7.07 & 10.18 & 0.49 & 7.37 & 0.19 & 422.87 & Safe & $\begin{array}{c}\text { Slightly } \\
\text { perceptible }\end{array}$ \\
\hline & 40 & 7.63 & 14.15 & 0.52 & 6.40 & 0.21 & 342.86 & Safe & $\begin{array}{c}\text { Slightly } \\
\text { perceptible }\end{array}$ \\
\hline & 45 & 8.34 & 19.56 & 0.54 & 5.69 & 0.22 & 278.82 & Safe & $\begin{array}{c}\text { Slightly } \\
\text { perceptible }\end{array}$ \\
\hline & 50 & 9.03 & 25.59 & 0.56 & 5.07 & 0.23 & 231.76 & Safe & $\begin{array}{c}\text { Slightly } \\
\text { perceptible }\end{array}$ \\
\hline \multirow{5}{*}{14} & 30 & 7.69 & 5.62 & 0.56 & 7.15 & 0.22 & 453.58 & Safe & $\begin{array}{c}\text { Slightly } \\
\text { perceptible }\end{array}$ \\
\hline & 35 & 8.77 & 8.53 & 0.58 & 6.06 & 0.23 & 340.90 & Safe & $\begin{array}{c}\text { Slightly } \\
\text { perceptible }\end{array}$ \\
\hline & 40 & 9.48 & 11.94 & 0.62 & 5.28 & 0.25 & 275.95 & Safe & $\begin{array}{c}\text { Slightly } \\
\text { perceptible }\end{array}$ \\
\hline & 45 & 10.2 & 16.02 & 0.66 & 4.66 & 0.26 & 227.97 & Safe & $\begin{array}{c}\text { Slightly } \\
\text { perceptible }\end{array}$ \\
\hline & 50 & 11.08 & 21.13 & 0.68 & 4.16 & 0.27 & 188.88 & Safe & $\begin{array}{c}\text { Slightly } \\
\text { perceptible }\end{array}$ \\
\hline \multirow{2}{*}{16} & 35 & 7.83 & 6.07 & 0.82 & 5.41 & 0.33 & 381.83 & Safe & $\begin{array}{c}\text { Slightly } \\
\text { perceptible }\end{array}$ \\
\hline & 40 & 10.53 & 9.83 & 0.75 & 4.54 & 0.30 & 248.43 & Safe & $\begin{array}{c}\text { Slightly } \\
\text { perceptible }\end{array}$ \\
\hline
\end{tabular}

Table 14 Fundamental frequency $(\mathrm{Hz})$ of bridges

\begin{tabular}{|c|c|c|c|c|}
\hline Mesh Size $(\mathrm{mm})$ & Straight & $\begin{array}{c}\text { Skew } \\
\left(\theta=60^{\circ}\right)\end{array}$ & $\begin{array}{c}\text { Curved } \\
\left(\alpha=48^{\circ}\right)\end{array}$ & $\begin{array}{c}\text { Skew-curved } \\
\left(\theta=60^{\circ} \& \alpha=48^{\circ}\right)\end{array}$ \\
\hline 500 & 1.762 & 1.925 & 1.753 & 2.235 \\
\hline 450 & 1.598 & 1.895 & 1.592 & 2.052 \\
\hline 400 & 1.456 & 1.782 & 1.498 & 1.925 \\
\hline 350 & 1.325 & 1.685 & 1.326 & 1.725 \\
\hline 300 & 1.235 & 1.468 & 1.246 & 1.625 \\
\hline 250 & 1.182 & 1.392 & 1.198 & 1.405 \\
\hline 200 & 1.170 & 1.251 & 1.185 & 1.332 \\
\hline 150 & 1.162 & 1.242 & 1.179 & 1.323 \\
\hline 100 & 1.159 & 1.201 & 1.172 & 1.321 \\
\hline 90 & 1.158 & 1.198 & 1.169 & 1.319 \\
\hline 80 & 1.158 & 1.195 & 1.168 & \\
\hline
\end{tabular}




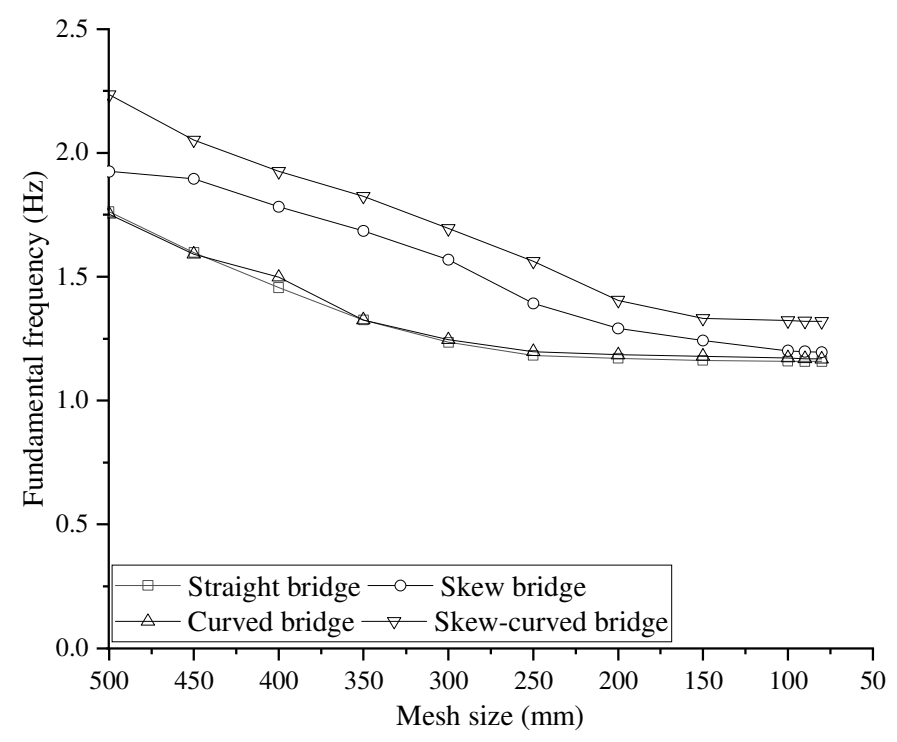

Fig. 9 Fundamental frequency of different box-girder bridges

\section{CONCLUSIONS}

This paper presents an essential concept and modelling procedure for box-girder bridges to assist designers in analysing and designing processes. In the present study, the proposed modelling procedure was applied to analyse the different types of RC box-girder bridges up to $50 \mathrm{~m}$ spans, without pre-stressing. However, the proposed modelling procedure may be extended to analyse any box-girder bridge with large spans. The cross-section of the bridge is selected according to the IRC 21: specifications. The static similitude procedure overestimates the cross-section of box-girder bridges and gives almost a solid section. Still, the cross-section can significantly be reduced using the trial and error process. Stresses, deflection, and frequency of the bridges for different span lengths, span-depth ratios, and cell numbers can be estimated. However, some cross-sections couldn't be modelled because they did not meet the strength, serviceability, and inspection requirements stated in the IRC. The results obtained by adopting the proposed modelling process are within a variation of 5\% compared to the published results. Thus, the proposed methodology may help the designers in analysing the straight, skew, curved, and skew-curved RC bridges for any loading conditions.

\section{LIST OF NOTATIONS}

$L \quad$ Span of bridge

$L / d \quad$ Span-depth ratio

$K_{L} \quad$ Scale reduction factor for the span

$L_{p} \quad$ Span of prototype

$L_{m} \quad$ Span of model

$K_{A} \quad$ Scale reduction factor for the area

$K_{Z} \quad$ Scale reduction factor for section modulus

$K_{I} \quad$ Scale reduction factor for the moment of inertia 


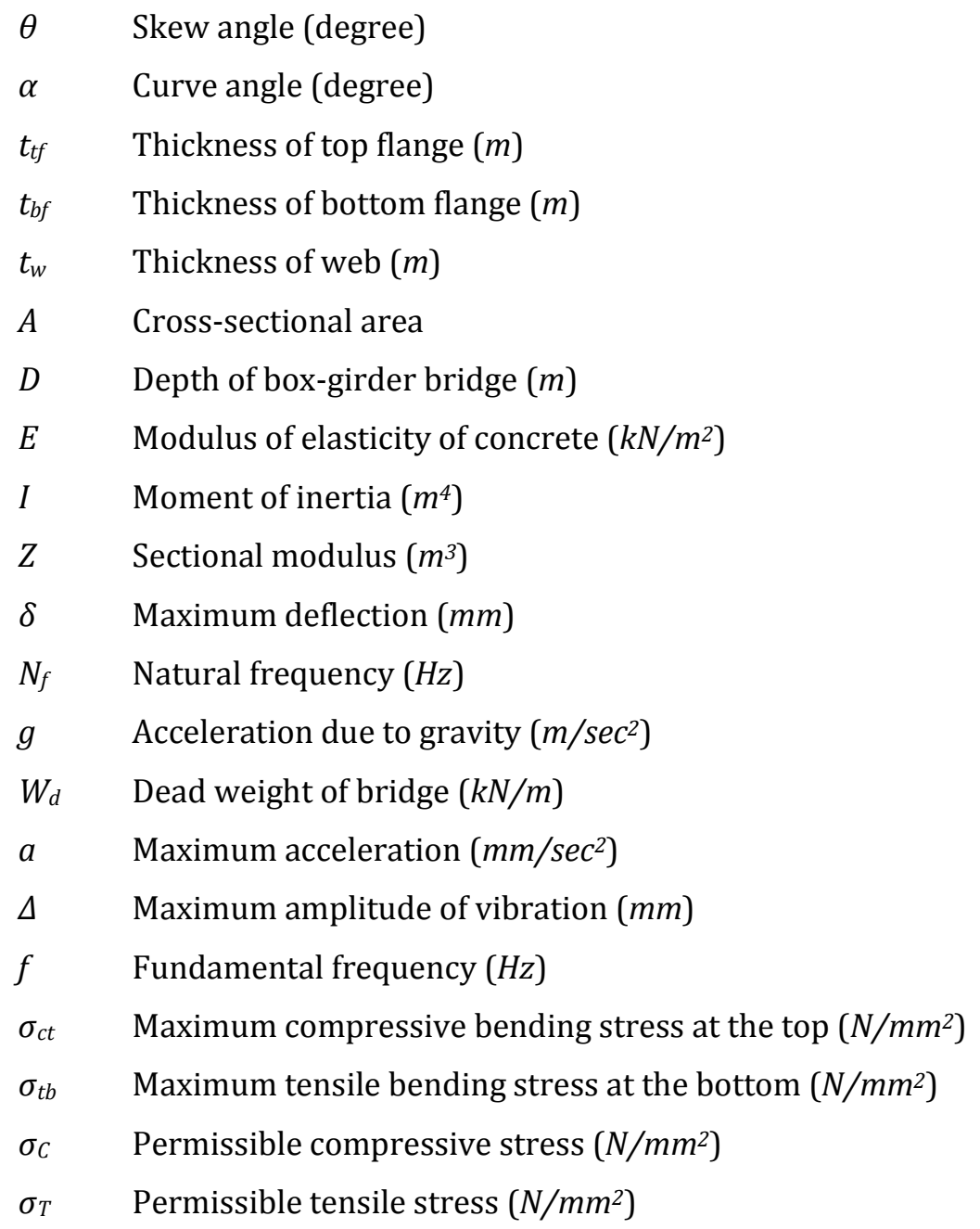

\section{ACKNOWLEDGMENT}

The authors acknowledge Motilal Nehru National Institute of Technology Allahabad for providing financial support under TEQIP - III.

\section{REFERENCES}

[1] T.G. Brown, A. Ghali, Semi-analytic solution of skew box girder bridges, P I Civil Eng. Part 2, Vol. 59, pp. 487-500, 1975. https://doi.org/10.1680/iicep.1975.3677

[2] C.P. Heins, J.C. Oleinik, Curved box beam bridge analysis, Comput Struct., Vol. 6, No. 2, pp. 65-73, 1976. https://doi.org/10.1016/0045-7949(76)90054-7

[3] D.E. Panayotounakos, P.S. Theocaris, A closed form solution for the static analysis of continuous skew-curved beam, Acta Mech., Vol. 37, pp. 53-64, 1980.

https://doi.org/10.1007/BF01441243

[4] M.S. Cheung, B. Bakht, L.G. Jaeger, Analysis of box girder bridges by grillage and orthotropic plate methods, Can J Civil Eng., Vol. 9, No. 4, pp. 595-601, 1982.

https://doi.org/10.1139/182-069 
[5] H.R. Evans, N.E. Shanmugam, Simplified analysis for cellular structures, J Struct Div, Vol. 110, No. 3, pp. 531-543, 1984.

https://doi.org/10.1061/(ASCE)0733-9445(1984)110:3(531)

[6] S.H. Zhang, L.P.R Lyons, A thin-walled box beam finite element for curved bridge analysis, Comput Struct., Vol. 18, No. 6, pp. 1035-1046, 1984.

https://doi.org/10.1016/0045-7949(84)90148-2

[7] K.W. Shushkewich, Approximate analysis of concrete box girder bridges, J Struct Eng.ASCE, Vol. 114, No.7, pp. 1644-1657, 1988.

https://doi.org/10.1061/(ASCE)0733-9445(1988)114:7(1644)

[8] W.Y. Li, L.G. Tham, Y.K. Cheung, Curved box-girder bridges, J Struct Eng.-ASCE, Vol. 114, No. 6, pp. 1324-1338, 1988.

https://doi.org/10.1061/(ASCE)0733-9445(1988)114:6(1324)

[9] Y. Arizumi, S. Hamada, T. Oshiro, Behavior study of curved composite box girders, $J$ Struct Eng.-ASCE, Vol. 114, No. 6, pp. 2555-2573, 1988.

https://doi.org/10.1061/(ASCE)0733-9445(1988)114:11(2555)

[10] B. Bakht, Analysis of some skew bridges as right bridges, J Struct Eng., Vol. 114, No. 10, pp. 2307-2322, 1988. https://doi.org/10.1061/(ASCE)0733-9445(1988)114:10(2307)

[11] T. Ebeido, J.B. Kennedy, Shear distribution in simply supported skew composite bridges, Can J Civil Eng., Vol. 22, No.6, pp. 1143-1154, 1995.

https://doi.org/10.1139/195-132

[12] T. Ebeido, J.B. Kennedy, Girder moments in continuous skew composite bridges, J Bridge Eng., Vol. 1, No. 37, pp. 37-45, 1996.

https://doi.org/10.1061/(ASCE)1084-0702(1996)1:1(37)

[13] Q.Z Luo, Q.S. Li, Shear lag of thin-walled curved box girder bridges, J Eng Mech.-ASCE, Vol. 126, No. 10, pp. 1111-1114, 2000.

https://doi.org/10.1061/(ASCE)0733-9399(2000)126:10(1111)

[14] X. Huo, S. Corner, R. Iqbal, Re-examination of the Simplified Method (Henry's Method) of distribution factors for live load moment and shear. Final Report, Tennessee DOT Project No. TNSPR-RES, 1218, 2003.

[15] S.T. Song, Y.H. Chai, S.E. Hida, Live-load distribution factors for concrete box-girder bridges, J Bridge Eng., Vol. 8, No.5, pp. 273-280, 2003.

https://doi.org/10.1061/(ASCE)1084-0702(2003)8:5(273)

[16] V.S. Jawanjal, M. Kumar, Finite element analysis of skew-curved RC box girder bridges, Adv Bridge Eng., pp. 183-190, 2006.

[17] D.B. Ashebo, T.H. Chan, L. Yu, Evaluation of dynamic loads on a skew box girder continuous bridge Part I: Field test and modal analysis, Eng Struct., Vol. 29, No. 6, pp. 1052-1063, 2007. https://doi.org/10.1016/j.engstruct.2006.07.014

[18] S. Ates, Numerical modelling of continuous concrete box girder bridges considering construction stages, Appl Math Model., Vol. 35, No.8, pp. 3809-3820, 2011.

https://doi.org/10.1016/j.apm.2011.02.016 
[19] Q.T. Su, G.T. Yang, C. Wu, Experimental investigation on inelastic behavior of composite box girder under negative moment, Int J Steel Struct., Vol. 12, pp. 71-84, 2012. https://doi.org/10.1007/s13296-012-1007-0

[20] L. Fangping, Z. Jianting, The deformation analysis of the curved box girder bridges under different radius, Mod Appl Sci., Vol. 6, No. 4, pp. 71-76, 2012.

https://doi.org/10.5539/mas.v6n4p71

[21] I. Mohseni, A.R. Rashid, Transverse load distribution of skew cast-in-place concrete multicell box-girder bridges subjected to traffic condition, Lat Am J Solids Stru, Vol. 10, No. 2, pp. 247-262, 2013. https://doi.org/10.1590/S1679-78252013000200002

[22] Y. C. Choi, B.H. Oh, Transverse modeling of concrete box-girder bridges for prediction of deck slab ultimate load capacity, J Bridge Eng., Vol. 18, No. 12, pp. 1373-1382, 2013. https://doi.org/10.1061/(ASCE)BE.1943-5592.0000489

[23] M. Arici, M.F. Granata, M. Oliva, Influence of secondary torsion on curved steel girder bridges with box and I-girder cross-sections, KSCE J Civ Eng., Vol. 19, pp. 2157-2171, 2015. https://doi.org/10.1007/s12205-015-1373-1

[24] M. Arici, M.F. Granata, Effects of secondary torsion in curved prestressed concrete bridges built by incremental launching method, Int J Bridge Eng., pp. 1-21, 2016.

[25] Y. Deng, B.M. Phares, L. Greimann, G.L. Shryack, J.J. Hoffman, Behavior of curved and skewed bridges with integral abutments, J Constr Steel Res., 109, pp. 115-136, 2015.

https://doi.org/10.1016/i.jcsr.2015.03.003

[26] D. Fan, H. Jian, Y. Shangyou, Z. Zhengjiiu, The main modes analysis of continuous curved box-girder bridge, In $5^{\text {th }}$ Int. Conf. Adv. Des. Manufact. Eng., pp. 1089-1095, 2015.

[27] K. Kashefi, A.H. Sheikh, M.M. Ali, M.C. Griffith, An efficient modelling approach based on a rigorous cross-sectional analysis for analysing box girder bridge superstructures, $A d v$ Struct Eng., Vol. 19, No. 3, pp. 513-528, 2016.

https://doi.org/10.1177/1369433216630121

[28] A. Androus, H.M. Afefy, K. Sennah, Investigation of free vibration and ultimate behavior of composite twin-box girder bridges, J Constr Steel Res., 130, pp. 177-192, 2017. https://doi.org/10.1016/i.jcsr.2016.12.017

[29] S. Tiwari, P. Bhargava, Load distribution factor for composite multicell box girder bridges, J Inst Eng. (India): Series A, 98, pp. 483-492, 2017.

https://doi.org/10.1007/s40030-017-0243-x

[30] N. Gupta, P. Agarwal, P. Pal, Free vibration analysis of RCC curved box girder bridges, Int J Tech Innov Mod Eng Sci., Vol. 5, No.2, pp. 1-7, 2019.

[31] N. Gupta, P. Agarwal, P. Pal, Analysis of RCC curved box girder bridges, Appl Innov Res., Vol. 1, No.3, pp. 153-159, 2019.

[32] P. Agarwal, P. Pal, P.K. Mehta, Analysis of RC skew box girder bridges, Int J Sci Innov Eng Tech., 6, pp. 1-8, 2019.

[33] P. Agarwal, P. Pal, P.K. Mehta, Finite Element Analysis of Skew Box-Girder Bridges, J Struct Eng. (Madras), Vol. 47, No. 3, pp. 1-16,2020.

[34] T. Gupta, M. Kumar, Flexural response of skew-curved concrete box-girder bridges, Eng Struct., Vol. 163, pp. 358-372, 2018. 
https://doi.org/10.1016/j.engstruct.2018.02.063

[35] P. Agarwal, P. Pal, P.K. Mehta, Parametric Study on Skew-Curved RC Box-Girder Bridges, Structures, 28, pp. 380-388, 2020.

https://doi.org/10.1016/j.istruc.2020.08.025

[36] CSiBridge, Analysis Reference Manual Version 20.0.0, Comput Struct. Berkeley, CA, 2016.

[37] IRC 21:2000, Standard specification and code of practice for road bridges, section IIIcement concrete (planed and reinforced), New Delhi, India, 2000.

[38] IRC 112:2011, Code of practice for concrete road bridges, New Delhi, India, 2000.

[39] N. Rajagopalan, Bridge superstructure. Narosa Publication, 2013.

[40] IRC 6:2014, Standard specifications and code of practice for road bridges, section II, loads \& stresses, New Delhi, India, 2014.

[41] EN 1991-2 (2003): Eurocode 1: Actions on structures - Part 2: Traffic loads on bridges, Brussels.

[42] V.K. Raina, Concrete bridge practice: Analysis, Design and Economics (2 ${ }^{\text {nd }}$ ed.), McGrawHill Education, 1994. 